\title{
Evaluation Of Peroxidase (POD) Activity Of Mango (Mangifera indica) Fruit Pulp At Different Level Of Ripeness
}

\author{
S. C. Ortutu and M. O. Aremu \\ iNnamdi Azikiwe University, Awka, Anambra State, Nigeria \\ ${ }^{2}$ Department of Chemical Sciences, Federal University Wukari, PMB 1020, Taraba State, Nigeria \\ *Corresponding Author : stellaortutu@gmail.com 08055133263 \\ DOI: 10.29322/IJSRP.11.09.2021.p11754 \\ http://dx.doi.org/10.29322/IJSRP.11.09.2021.p11754
}

\begin{abstract}
Crude peroxidase (POD) was extracted from unripe (UR), about to ripe (AR) and ripe (RP) mango (Mangifera indica) fruit pulp using a spectrophotometer and pyrogallol as the substrate. Peroxidase activity, the effect of $\mathrm{pH}$ and temperature on peroxidase activity and the kinetics of the fruit pulps were studied. The result showed that peroxidase activity was present in all the mango samples investigated. Peroxidase activity increased as the fruit pulp ripened and was highest in the ripe (RP) sample. Peroxidase enzyme exhibited maximum activity at $\mathrm{pH}$ 5.5, 6.0 and 6.5 for UR, AR and RP samples respectively. All the samples showed high enzyme activity at temperatures $10{ }^{\circ} \mathrm{C}$ to $20^{\circ} \mathrm{C}$. At $70{ }^{\circ} \mathrm{C}, 50 \%$ enzyme activity was lost in AR sample while $60 \%$ activity was lost in UR and AR samples. The enzyme in all the samples were completely inactivated when incubated at $90{ }^{\circ} \mathrm{C}$. The Michaelis- Menten constant $(\mathrm{km})$ for AR, UR and RP samples were $0.283 \mathrm{M}, 0.463 \mathrm{M}$ and $0.477 \mathrm{M}$ respectively with a maximum enzyme velocity (Vmax) of $0.020,0.028$ and 0.030 enzyme unitts/g fruit pulp for UR, AR and RP samples respectively. The value of km suggests that POD from unripe (UR), about to ripe (AR) and ripe (RP) Mangifera indica fruit pulp can be isolated, purified, characterized and quantitatively made available for biotechnological applications.
\end{abstract}

Keywords: Enzyme, UR, AR, RP, Mango, peroxidase, pH, temperature

\section{Introduction}

Mango (Mangifera indica) belongs to the Anacardiacea family. It is a tropical fruit of Asian origin which is considered as the king of fruits [1]. The mango fruits are very popular world-wide with India having the highest production followed by China, Thailand, Mexico, Pakistan, Indonesia, the Philippines, Nigeria and Brazil [2]. The fruit of mango is a fleshly drupe which is kidney-shaped or oval. It ranges from 5 to $15 \mathrm{~cm}$ in length, yellowish or reddish in colour.

Peroxidase (POD) is an oxidoreductase enzyme which catalyses the reduction of peroxides such as hydrogen peroxide and the oxidation of a variety of organic and inorganic compounds. Peroxidase enzymes catalyse phenol oxidation and are classified as phenolase which are oligomers in food and contain one copper prosthetic group per subunit. The oxidation of phenols is responsible for browning reactions in most fruits [3]. Enzymatic browning is very common at the cut surface of light coloured fruits [4]. The cut surface may rapidly change to brown colour due to the oxidation of phenols to orthoquinones which rapidly polymerise to form brown pigments or melanins [4].

Peroxidases are distributed in plants like radish, soybean, tomato, potato, turnip, carrot, wheat, pear, apricot and banana dates [5]. It is also reported in fruits like oranges [6], peach [7], pears [8] and apples [9]. POD have been associated with many metabolic and physiological changes in tissues, extension polymerization, auxin metabolism, disease resistance, ripening and senescence of fruits [10]. The enzyme has been found to be involved in deteriorative changes in flavor, texture and colour of processed and raw fruits and vegetables [11]. POD from plants exist as isoenzymes and its number may vary from one vegetable source to another [5]. They differ 
in terms of thermal stability, optimum $\mathrm{pH}$ substrate specificity, amino acid composition and their physiological roles in the plant tissue. Inhibition of plant enzymes is generally achieved using physical and chemical treatments such as heating (blanching), lowering $\mathrm{pH}$ or incorporating chemical additives [12].

Peroxidase is considered the most heat stable enzyme in plants. There is an empirical relationship between residual peroxidase activity and the development of off-flavours and off-odours in foods [13]. It plays an important role in the fields of biotechnology and associated research areas like enzymology, biochemistry, medicine, genetics, physiology and cytochemistry [14]. It is also applied in health sciences as a diagnostic tool [15]. In recent years' peroxidases are used in processes like detoxification and removal of variety of organic pollutants from contaminated waste water [16].

Considering the importance of peroxidase enzyme and the fact that mango fruits are readily available in Nigeria, the aim of the study was to evaluate the peroxidase activity of mango fruit pulps at different level of ripeness, study the effect of $\mathrm{pH}$ and temperature on peroxidase activity of the fruit pulps and determine their kinetics.

\section{Materials and Methods}

Mango (Mangifera indica) fruits were harvested from FCT, Abuja, Nigeria. Based on visual observation of colour, texture and flavor, the fruits were categorized into unripe (UR), about to ripe (AR) and ripe (RP). The fruits were washed, their seed nuts removed and the pulp of the fruits cut into small pieces. The categorized and sliced fruit pulps were taken to the Medicinal Department of the National Institute of Pharmaceutical Research and Development (NIPRD) Idu, FCT, Abuja Nigeria for further treatment and analysis.

\section{Preparation of Samples}

The categorized and sliced fruit pulps were weighed, homogenized using a domestic blender, filtered using a cheese cloth and freezedried. The freeze-dried samples were stored in an air tight sample bottle and used for the analysis.

\section{Extraction of Crude Peroxidase (POD)}

Crude POD enzyme was extracted using the method described by [4] and [17]. The freeze dried fruit pulp samples (1.0 g) were mixed with $1.5 \mathrm{ml}$ prechilled $0.01 \mathrm{M}$ sodium phosphate buffer ( $\mathrm{pH}$ 6.0). The resulting mixtures were stirred at room temperature for $5 \mathrm{~min}$ to extract crude POD. This was then centrifuged at $10000 \mathrm{rpm}$ for $15 \mathrm{~min} 4{ }^{\circ} \mathrm{C}$ to remove all debris. The supernatant was carefully removed from the sediments and filtered using Whatman No 1 filter paper.

\section{Assay of Peroxidase (POD) Activity}

Assay of peroxidase activity was carried out according to the method of [18] and [4]. The crude POD extracts were diluted 5 times with $0.01 \mathrm{M}$ sodium phosphate buffer ( $\mathrm{pH}$ 6.5). A constant volume of $0.32 \mathrm{ml}$ of $5 \%$ pyrogallol was mixed with $0.4 \mathrm{ml}$ of each categorized crude enzyme extract and $0.16 \mathrm{ml}$ of $35 \%$ hydrogen peroxide solution. A portion of each enzyme - substrate mixture was rapidly transferred into a cuvette and the absorbance measured at $420 \mathrm{~nm}$ for $60 \mathrm{~s}$ interval up to $360 \mathrm{~s}$ using a UV-spectrophotometer. Before taking absorbance readings, the instrument was zeroed using the same combination of reagents above but without the enzyme extract. Replicate readings were taken for the test. The average of the replicated readings was taken. Enzyme activity was calculated using:

Enzyme units / g fruit pulp $=\frac{\Delta \text { Absorbance }(420 \mathrm{~nm}) \times \mathrm{Va} \times \mathrm{df}}{\Delta \text { Time }(\mathrm{s}) \times 12 \mathrm{Ve}}$

Where: $\mathrm{Va}=$ Vol. of assay, $\mathrm{df}=$ Dilution factor, $12=$ Extinction coefficient of $1.0 \mathrm{mg} / \mathrm{cm}^{3}$ of purpurogallin at $420 \mathrm{~nm} . \mathrm{Ve}=\mathrm{Vol}$. of enzyme extract used.

\section{Evaluation of effect of pH on POD Activity}

The effect of $\mathrm{pH}$ on POD activity was determined as described by [18]. $0.4 \mathrm{ml}$ of the diluted POD extract was mixed with $0.32 \mathrm{ml}$ of $0.01 \mathrm{M}$ sodium phosphate buffer $(\mathrm{pH} 4.0,4.5,5.0,5.5,6.0,6.5,7.0,7.5,8.0,8.5)$. The POD activity was tested as described earlier.

\section{Evaluation of the effect of temperature on POD Activity}

The effect of temperature on POD activity was determined as described by [18]. The diluted POD enzyme extract (0.4 ml) was mixed with $0.32 \mathrm{ml} 0.01 \mathrm{M}$ sodium phosphate buffer $(\mathrm{pH} 6.0)$ and was incubated for $10 \mathrm{~min}$ at varying temperatures ranging between $10{ }^{\circ} \mathrm{C}$ 
to $90{ }^{\circ} \mathrm{C}$ in an isotherm water bath. After incubation, the mixture was cooled in ice slurry and the activity determined as described above at the various temperatures.

\section{POD Kinetics}

The reaction rate of POD at a series of substrate concentration was determined as described by [4]. Hydrogen peroxide $\left(0.16 \mathrm{~cm}^{3}\right.$ of 35 $\%$ ) and a constant $0.4 \mathrm{~cm}^{3}$ of the diluted enzyme extract was mixed with $0.32 \mathrm{~cm}^{3}$ of $0.01 \mathrm{M}$ sodium phosphate buffer (pH 6.5) followed by $0.32 \mathrm{~cm}^{3}$ pyrogallol of the following concentrations (M) $0.05,0.10,0.15,0.20,0.25,0.30,0.35$ and 0.40 . The absorbance was measured immediately every $60 \mathrm{~s}$ interval up to $360 \mathrm{~s}$. The absorbance versus time and the reaction rate (enzyme activity) versus substrate concentration were plotted to fit the Michalis-Menten equation which was used to derive the Michalis-Menten constant (Km) and the maximum velocity (Vmax).

\section{Statistical Analysis}

Data were expressed as means \pm SD of three independent determinations. A nonlinear regression was used for enzyme activity.

\section{Result and Discussion}

Peroxidase enzyme (POD) were extracted from unripe (UR), about to ripe (AR) and ripe (RP) mango fruit pulps. The final extract obtained after centrifugation and filtration of each categorized fruit extract is the crude POD. There was no brown colour in all the crude POD extract before use. POD activity was spectrophotometrically measured at wavelength of 420 using pyrogallol as substrate. This method of peroxidase activity of fruits measurement provides a quantitative basis for determining the amount of the enzyme present in the fruit. The intensity of the characteristic brown colour produced during reaction expressed the amount of enzyme and the magnitude of the enzyme reaction in the crude extract. Peroxidase activity was shown by all the fruit pulps with activity (enzyme units'g fruit pulp) of mean $0.006 \pm 0.03,0.008 \pm 0.02$ and $0.03 \pm 0.01$ for UR, AR and RP respectively. This results showed that peroxidase activity increased as the fruit pulps ripened. The result of this analysis is in agreement with that of [19] who observed an increase in POD activity during the onset of ripening in banana and apple fruits. Peroxidase activity has also been identified in ripe pawpaw fruit pulp [20], apple seeds [17] and mango seed [4].

All the categorized crude POD fruit pulp extracts exhibited POD activity over $\mathrm{pH}$ range of 4.0-8.5. Figs 1a-c showed that the absorbance of all the fruit pulp extracts increased linearly within the initial $60 \mathrm{~s}$ displaying a first order enzymatic reaction behavior. The absorbance of all the fruit pulps increased gradually within 120 to $240 \mathrm{~s}$ assay time and reached a plateau after $240 \mathrm{~s}$. The absorbance of all the fruits initially increased to a $\mathrm{pH}$ of maximum activity and then decreased. This suggest that POD enzyme in the fruit pulps were unstable after their $\mathrm{pH}$ of maximum activity or that the residual proteins present in the enzyme extract might have reacted with the reaction product (Purpurogallin). The dependency of POD activity on $\mathrm{pH}$ followed a bell - shaped curve for all the fruit pulps (Figs. 1d-f). A maximum activity (enzyme units /g fruit pulp) of 0.009, 0.03 and 0.03 were seen at $\mathrm{pH} 5.5,6.0$ and 6.5 for UR, AR and RP samples respectively. The common range of $\mathrm{pH}$ for maximum activity is from 6.0 to 7.0 in fruits like blackberry [21], Spanish papaya [22], apples [23], raspberry [24], banana peel [25], pear [26] and ripe pawpaw [20] 


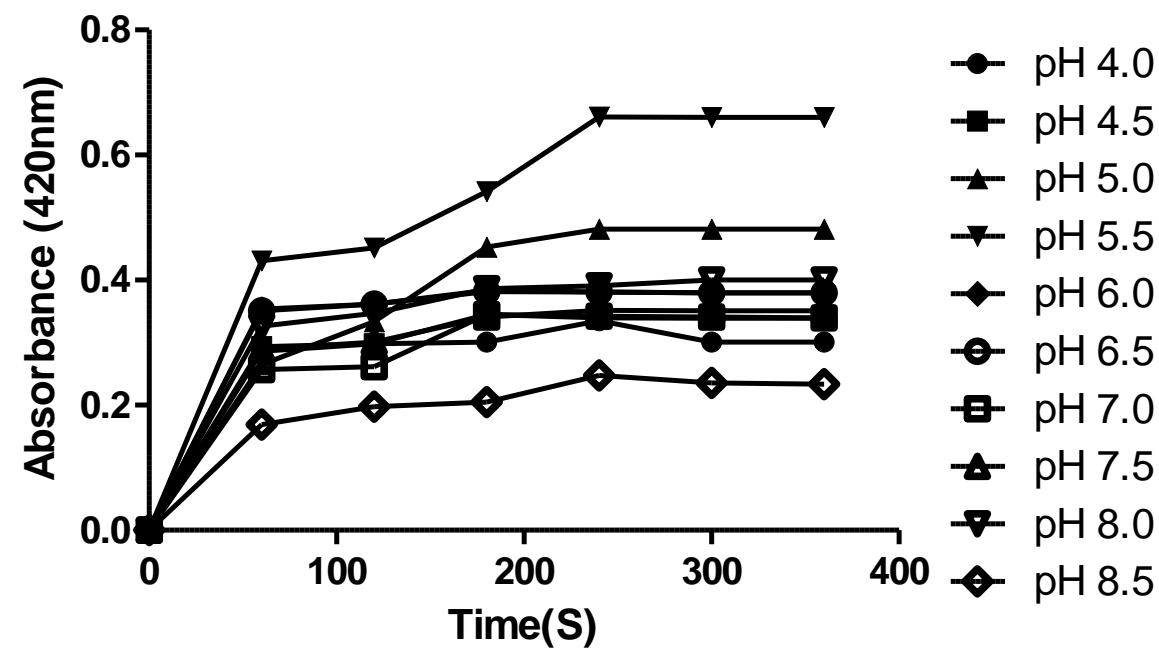

crude POD extracted from UR mango at room temperature.

Fig. 1a: Effect of $\mathrm{pH}$ on the activity (absorbance) of

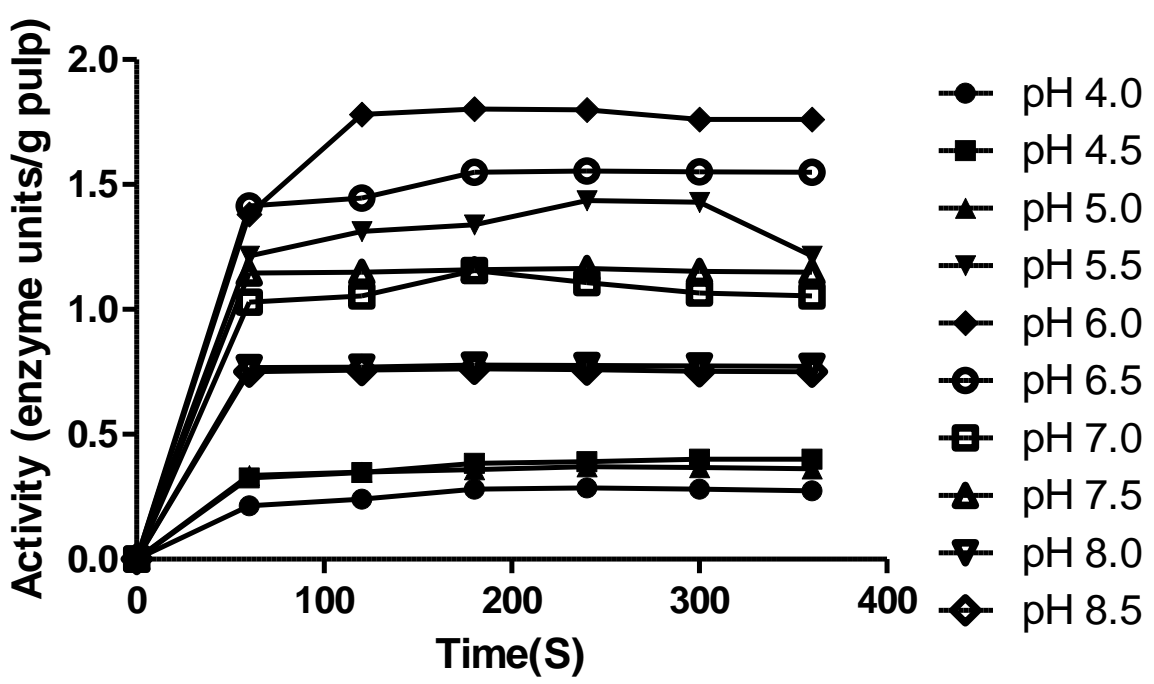

Fig. 1b: Effect of $\mathrm{pH}$ on the activity (absorbance) of crude POD extracted from AR mango at room temperature. 


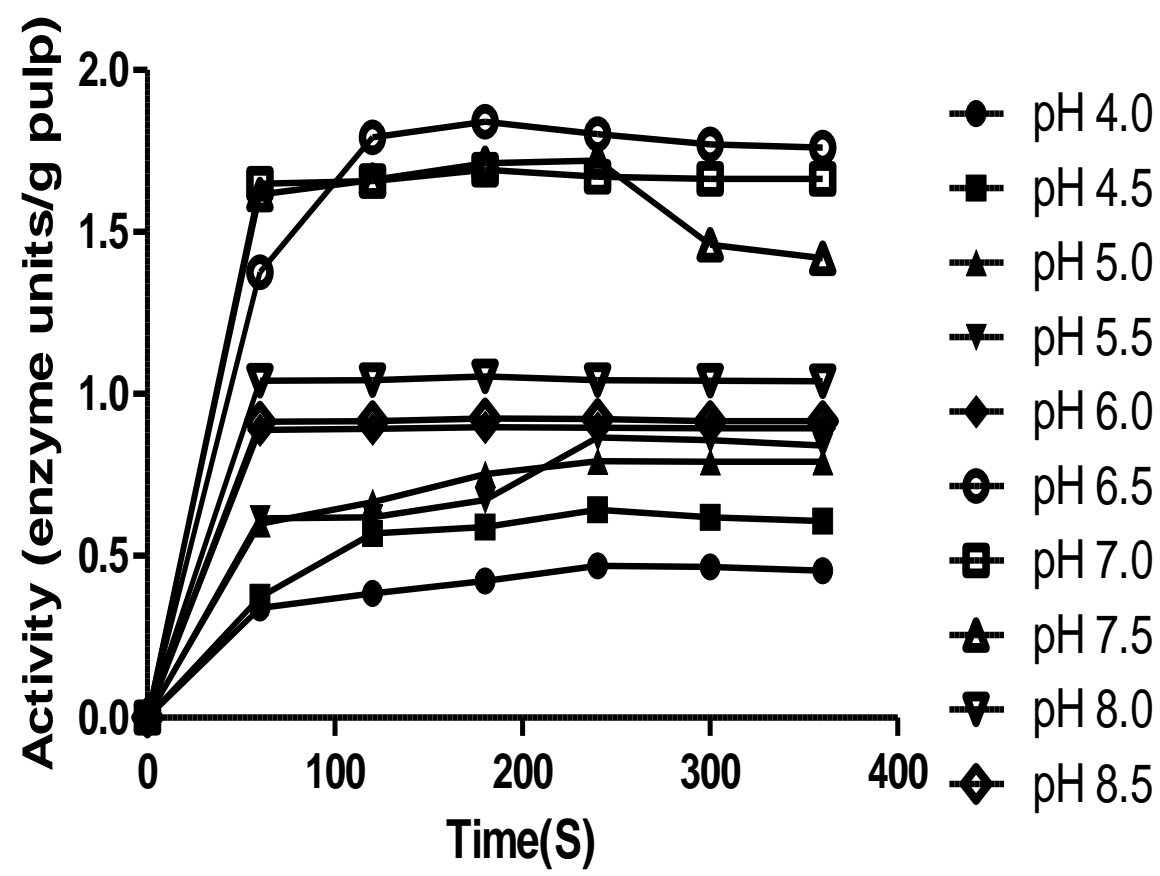

Fig. 1c: Effect of $\mathrm{pH}$ on the activity (absorbance) of crude POD extracted from RP mango at room temperature.

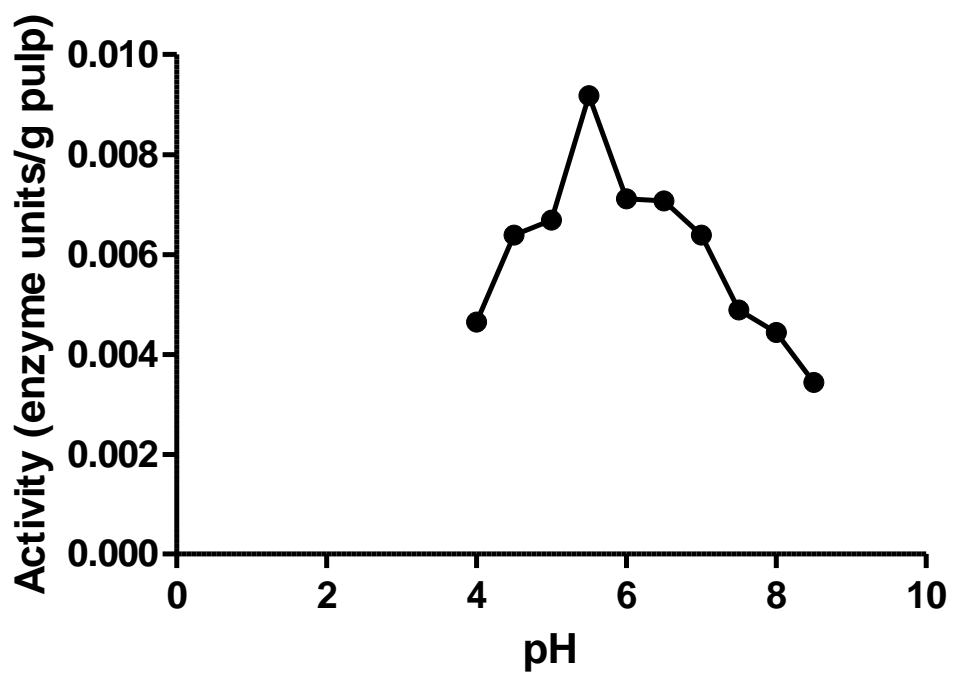

crude POD extracted from UR mangoes fruit pulp at room temperature

Fig. 1d: The optimum $\mathrm{pH}$ for 


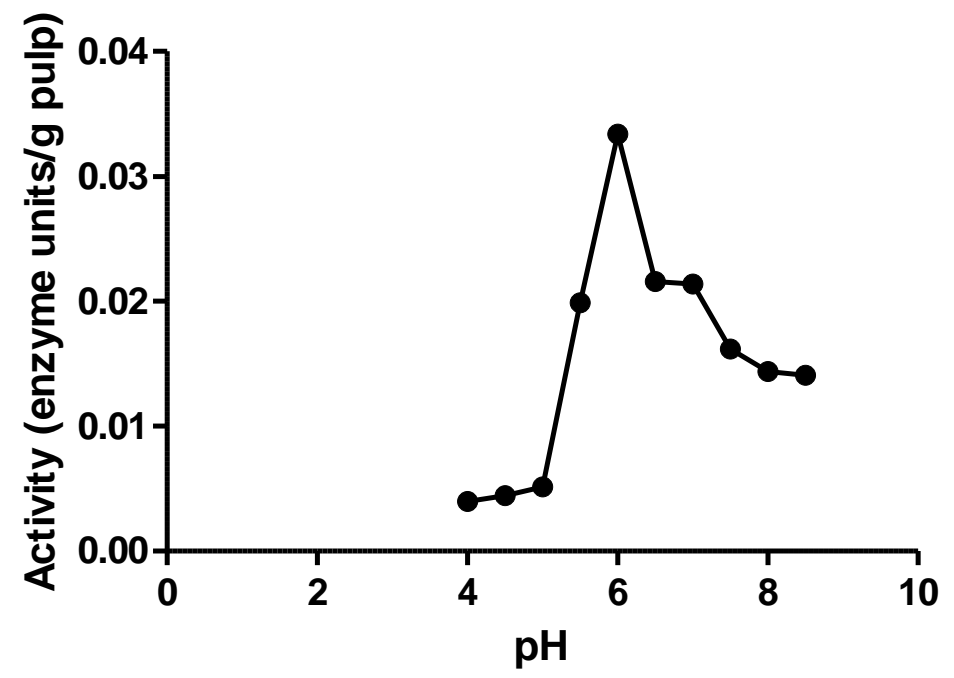

Fig. 1e: The optimum pH for crude POD extracted from AR mango fruit pulp at room temperature

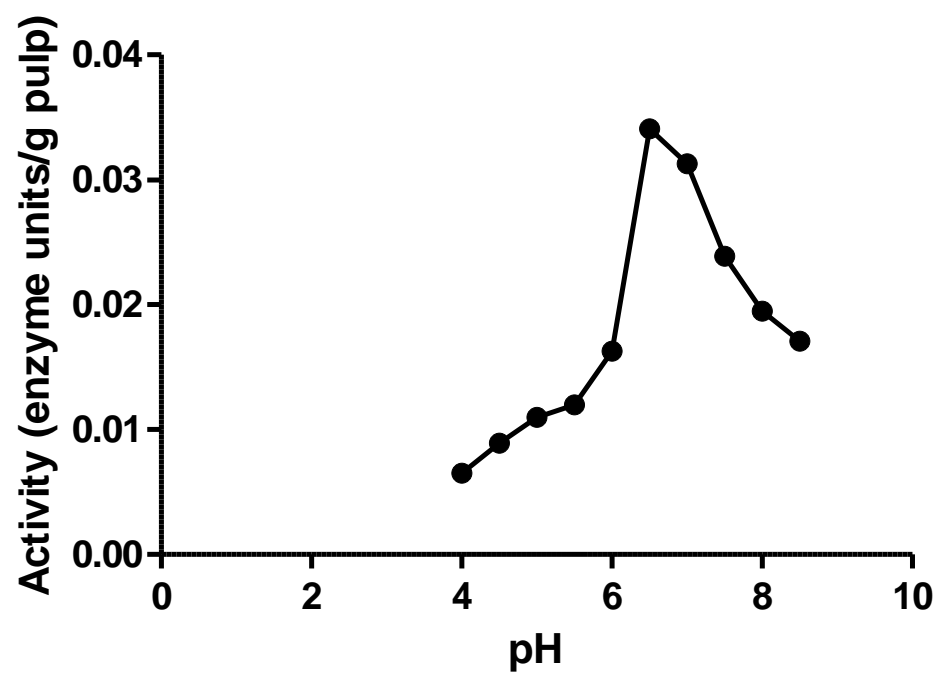

Fig. 1f: The optimum $\mathrm{pH}$ for crude POD extracted from RP mango fruit pulp at room temperature

The result of the activity of crude POD extract after 10 min exposure to temperatures ranging from $10{ }^{\circ} \mathrm{C}$ to $90{ }^{\circ} \mathrm{C}$ was shown in Figs. 2a-f for all the categorized fruit pulps. All the crude enzyme extract showed very high activity when incubated at $10{ }^{\circ} \mathrm{C}$ to $20^{\circ} \mathrm{C}(0.08$ enzyme units /g fruit pulp for UR, 0.056 enzyme units /g fruit pulp for AR and 0.13 enzyme units /g fruit pulp for RP. At $30{ }^{\circ} \mathrm{C}, \mathrm{POD}$ activity decreased for all the fruit pulps while the loss of POD activity became remarkable at $70{ }^{\circ} \mathrm{C}$; where about $50 \%$ activity was lost in unripe mango (RP) while more than $60 \%$ activity was lost in unripe (UR) and about to ripe (AR) samples. When the enzyme was heated to $90{ }^{\circ} \mathrm{C}, 90 \%$ of POD activity was lost in all the fruit pulps studied. These results showed that crude POD extracted from all the fruit pulps was stable over wide temperature ranges. This finding is in agreement with the suggestion of [27] that peroxidase enzyme is the most heat resistant enzyme and is used as an index of blanching procedures. Peroxidase enzyme from peach fruit was found to be 
stable at temperature of $60{ }^{\circ} \mathrm{C}$, marked inactivation occurred at temperature above $70{ }^{0} \mathrm{C}$ while at $80{ }^{\circ} \mathrm{C}$, the enzyme was completely inactivated [8]. [28] observed that tomato peroxidase was completely inactivated at $90{ }^{\circ} \mathrm{C}$ and $\mathrm{pH}$ of 6.0. The high activity of POD at 10 to $20{ }^{\circ} \mathrm{C}$ indicated the reaction of the enzyme with the substrate (pyrogallol) while the reduced activity at temperature of $70{ }^{\circ} \mathrm{C}$ was probably due to thermally induced irreversible denaturation changes in POD [29].

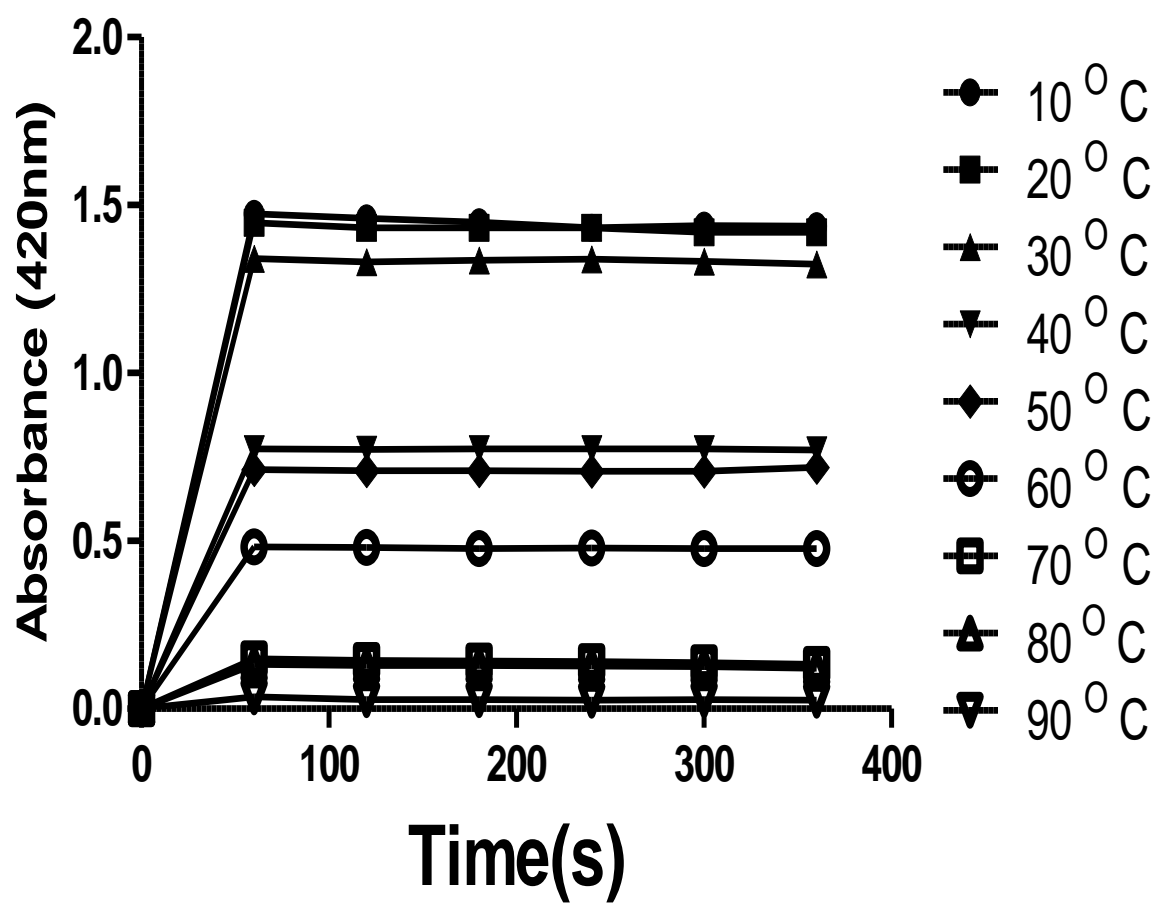

(Absorbance) of crude POD extracted from UR mango fruit pulp

Fig. 2a: Effect of heating (10 $\mathrm{min})$ on the activity

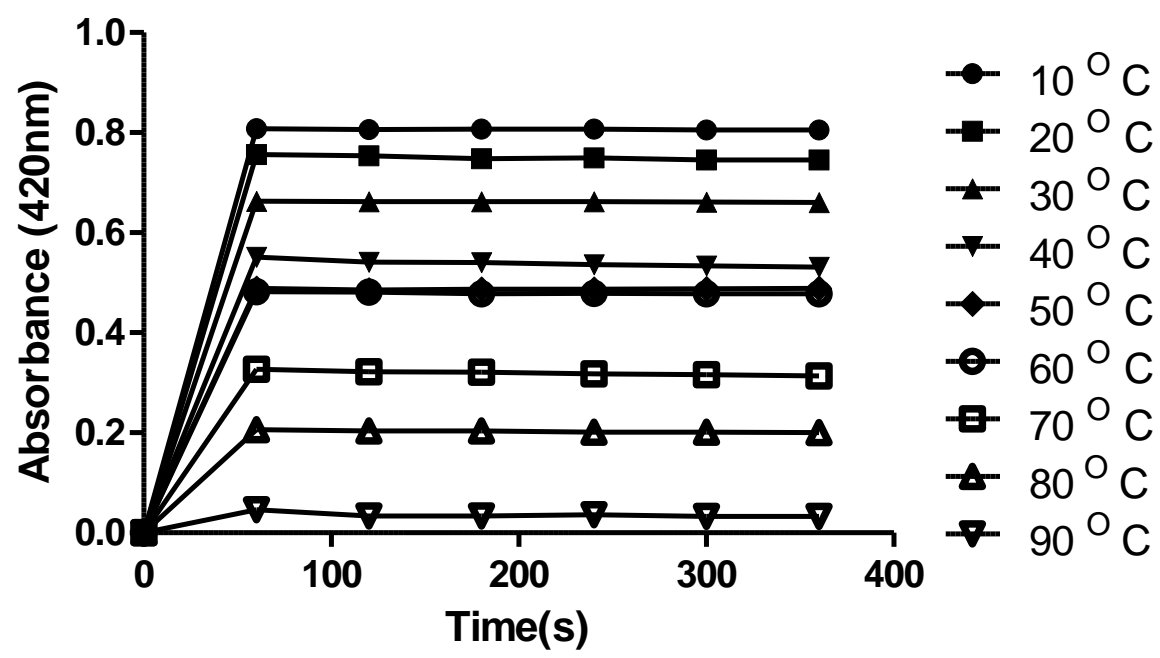

activity (Absorbance) of crude POD extracted from AR mango fruit pulp 


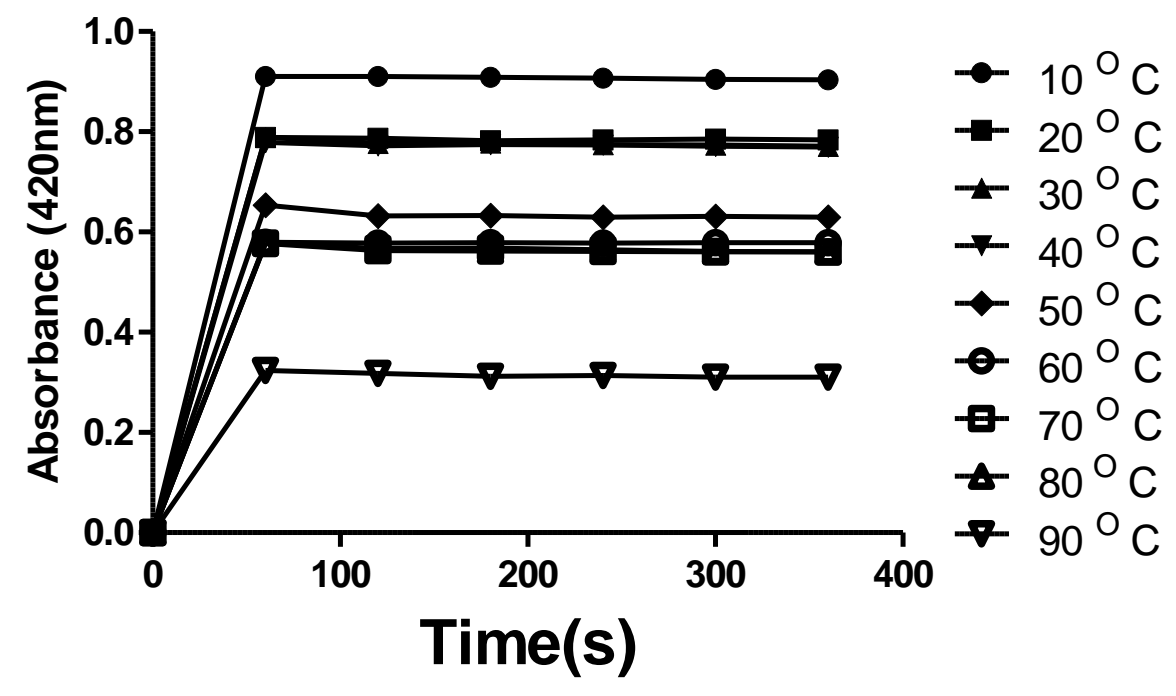

Fig. 2c: Effect of heating (10 min) on the activity (Absorbance) of crude POD extracted from RP mango fruit pulp

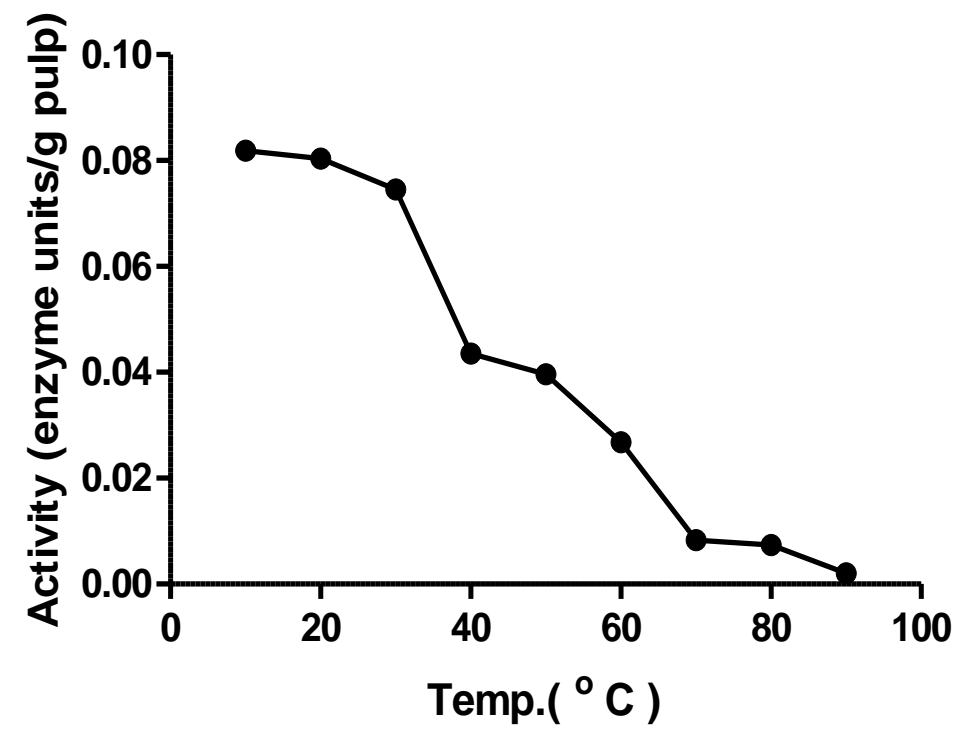

Fig. 2d: Influence of heating (10 min) on the activity (Absorbance) of crude POD extracted UR mango fruit pulp 


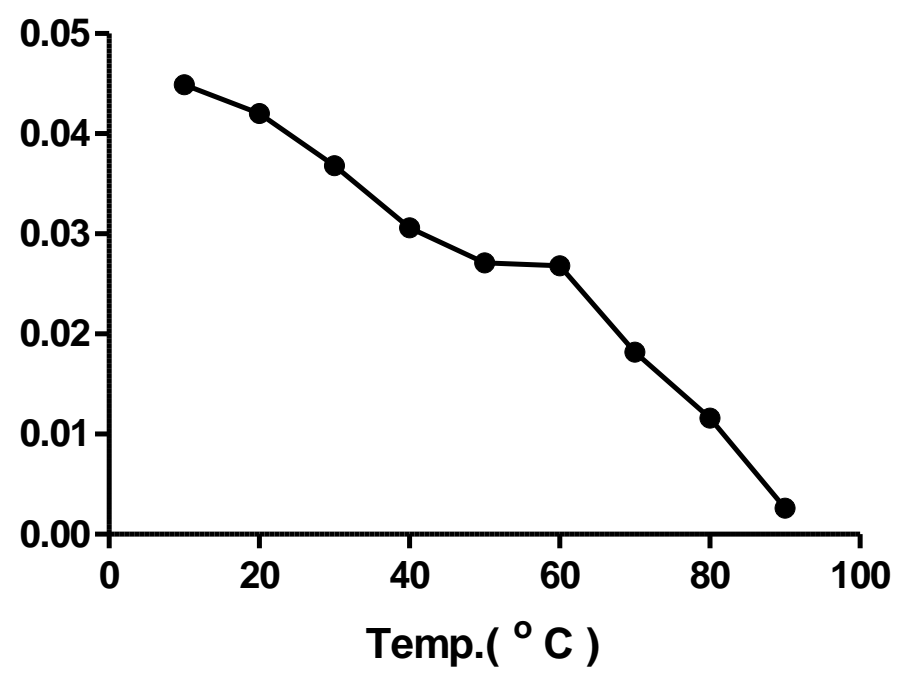

Fig. 2e: Influence of heating (10 min) on the activity (Absorbance) of crude POD

extracted AR mango fruit pulp

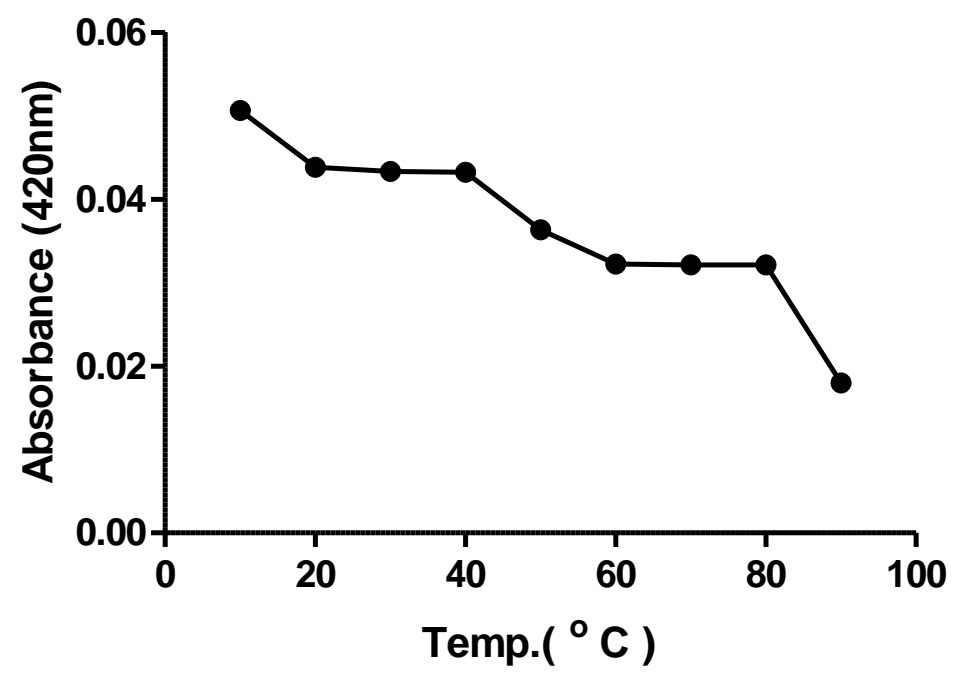

Fig. 2f: Influence of heating (10 min) on the activity (Absorbance) of crude POD extracted RP mango fruit pulp

Peroxidase enzyme kinetics was studied using substrate concentration ranging from 0.05 to $0.40 \mathrm{M}$. The plot of absorbance against substrate concentration (Fig 4.0a-c) showed that the absorbance increased linearly within the first $60 \mathrm{~s}$ of reaction time and reached a plateau between 120-240 s for UR, AR and RP samples. There was corresponding peroxidase activity as the substrate concentration increased for all the fruit pulps studied (Figs. 4.0d-f). This observation is in agreement with that of [30] who noted that adding more of the substrate would increase the reaction rate and that the maximum reaction rate that can be achieved by a certain enzyme level would be the reaction rate at the saturation point. The result of the activity (reaction rate) and substrate concentration (Fig. 4.0d-f) for UR, AR and RP samples were subjected to non-linear regression analysis to generate the Michaelis-Menten plot from where Km and Vm were obtained. $\mathrm{Km}(\mathrm{M})$ was found to be $0.283 \pm 0.01,0.463 \pm 0.03$ and $0.477 \pm 0.01$ for UR, AR and RP samples respectively while Vm (enzyme units/g fruit pulp) was $0.020,0.028$ and 0.030 for UR, AR and RP samples respectively. Km was highest in RP mango pulp suggesting that it increases as the fruit pulp ripened. Michaelis-Menten constant $(\mathrm{Km})$ is a measure of the affinity between an enzyme and its substrate which describes the rate of dissociation of the enzyme-substrate complex (ES). Large Km value represents low affinity 
and weak enzyme-substrate complex association whereas low Km indicates a strong enzyme-substrate complex and high affinity [4]. Peroxidase obtained from papaw with pyrogallol as substrate was found to have a Km value of 0.027 [31]. [32] reported a Km values of $0.16,0.2$ and 0.1 for pawpaw with o-dianisidine, guaiacol and phenylenediamine as substrate respectively. The affinity between POD enzyme and pyrogallol is stronger in unripe mango fruit pulp than the ripe fruit pulp. The study of peroxidase activity of mango (M.indica) kernel by [4] using pyrogallol as substrate gave $\mathrm{Km}$ of $1.48 \mathrm{Mm}$ and Vmax of 0.29 enzyme units/g kernels. Km of $8 \times 10^{-5}$ Mm and Vmax of 1.53 enzyme units/g kernel was obtained when hydroquinone was used as substrate for mango kernel peroxidase [33] while $\mathrm{Km}$ of $58 \mu \mathrm{M}$ and Vmax of 3.36 units/mmol were reported for French bean peroxidase using pyrogallol as substrate [34]. These results suggest that $\mathrm{Km}$ and Vmax values for peroxidase activity may vary with the type of substrate, source, fruit species, maturity and purity of the enzyme.

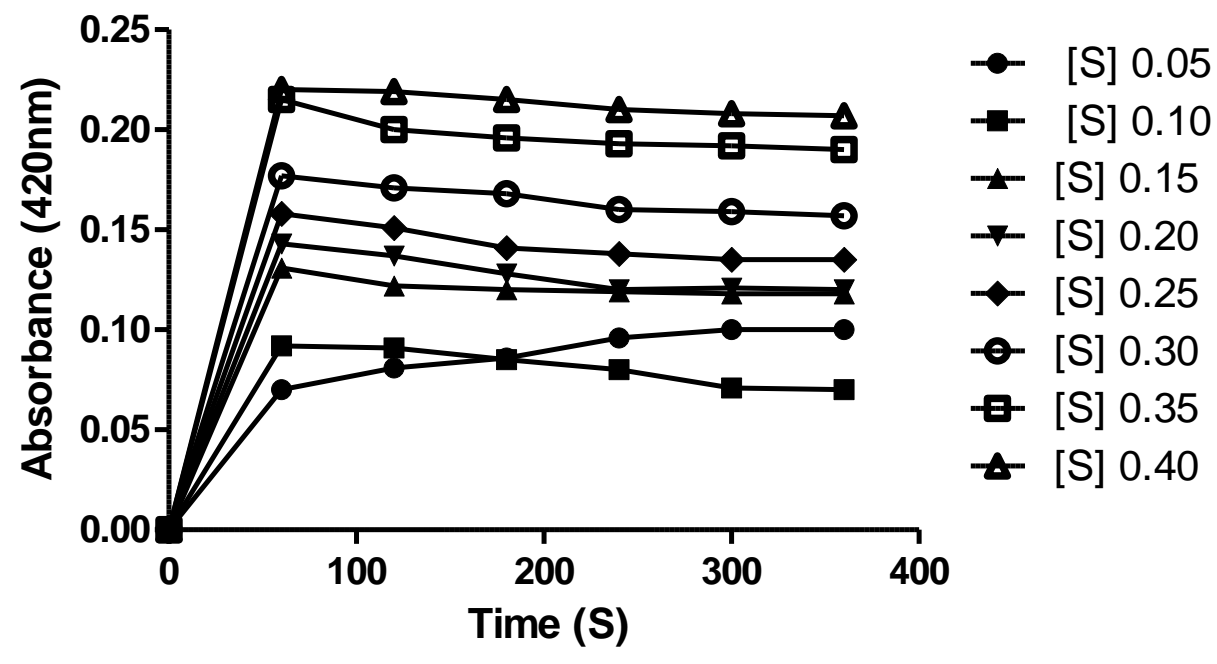

Fig.3a: Effect of substrate concentration on activity (Absorbance) of crude POD extracted from UR mango fruit pulp

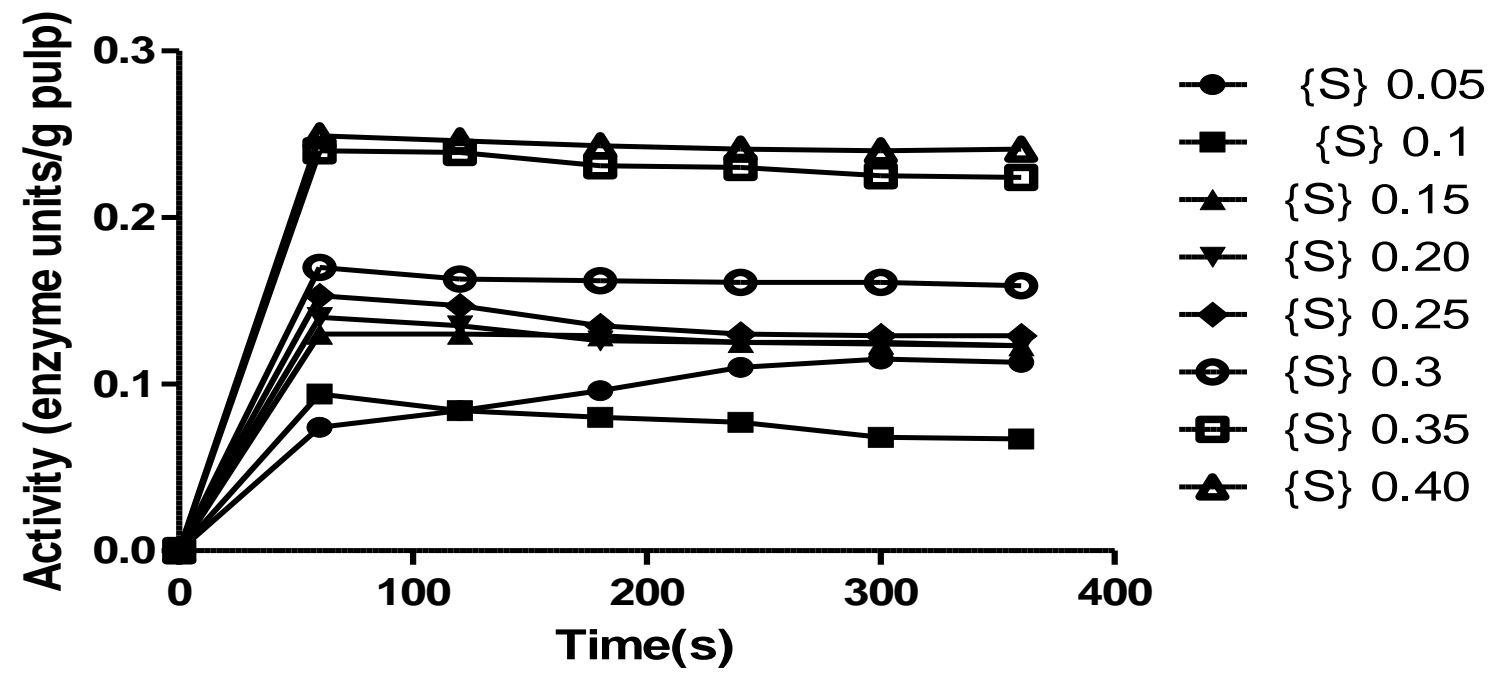

of substrate concentration on activity (Absorbance) of crude POD extracted from AR mango fruit pulp

Fig.3b: Effect 


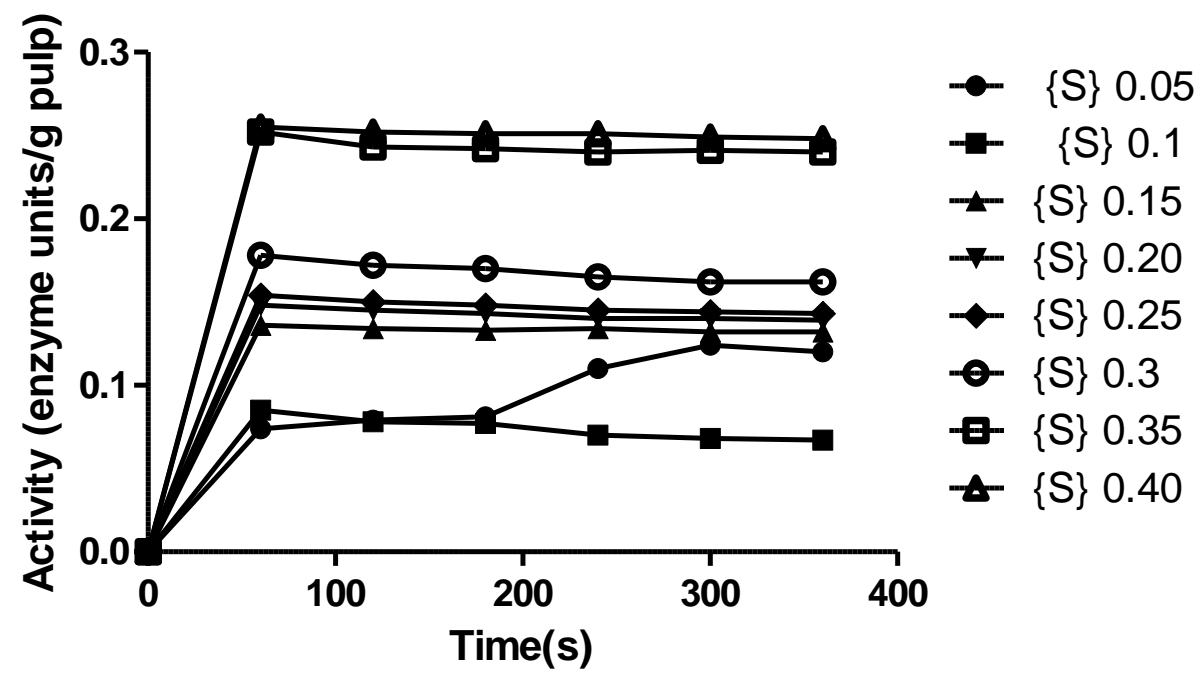

Fig.3c: Effect of substrate concentration on activity (Absorbance) of crude POD extracted from RP mango fruit pulp

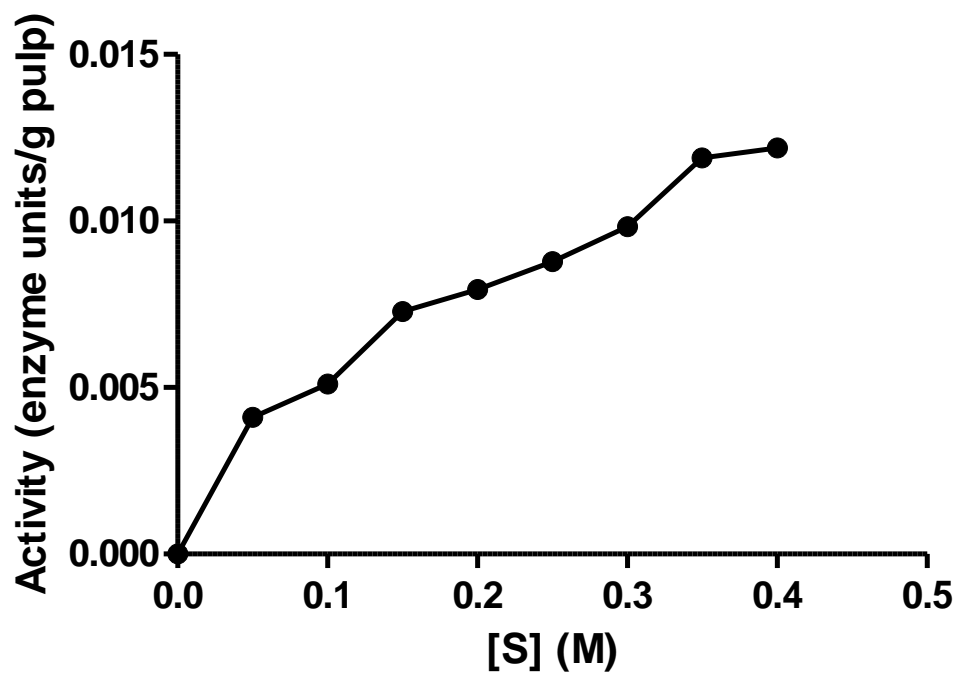

Fig. 3d: Michaelis-Menteu plot of reaction rate (activity versus substrate (pyrogallol) concentration for crude POD extracted from UR mango fruit pulp 


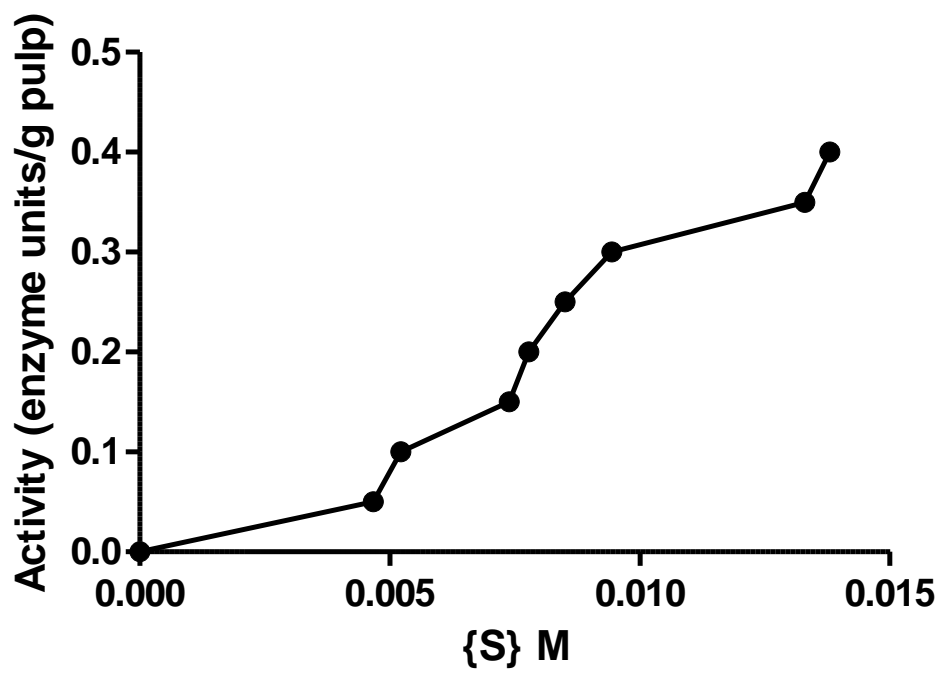

Fig. 3e: Michaelis-Menteu plot of reaction rate (activity versus substrate (pyrogallol)

concentration for crude POD extracted from AR mango fruit pulp

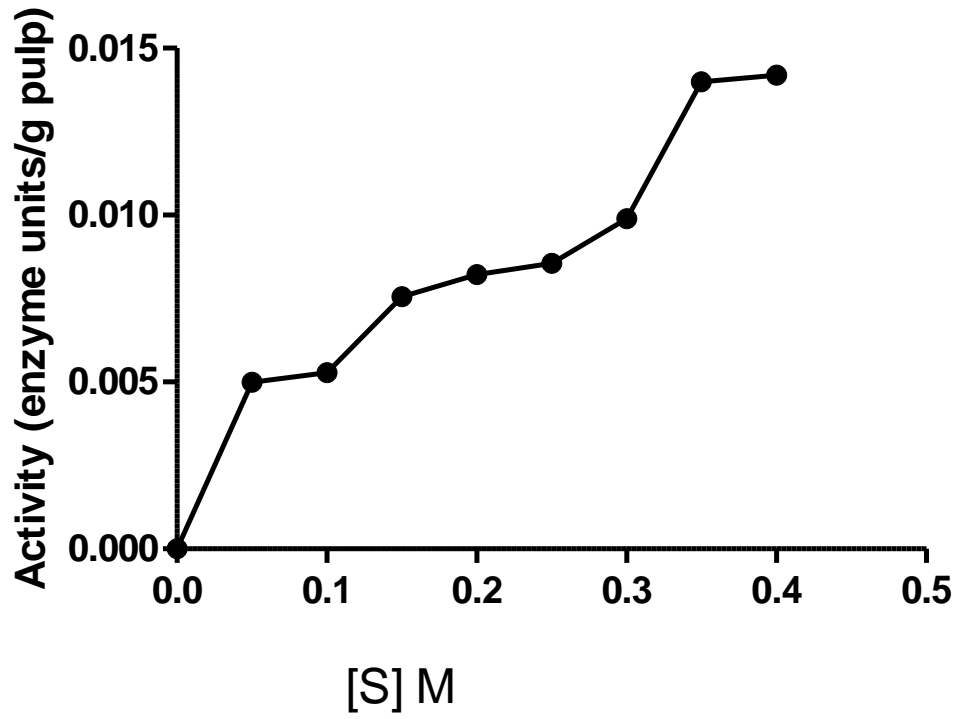

Fig. 3f: Michaelis-Menteu plot of reaction rate (activity versus substrate (pyrogallol)

concentration for crude POD extracted from RP mango fruit pulp

\section{Conclusion}

Unripe (UR), about to ripe (AR) and ripe (RP) Mangifera indica fruit pulps showed significant peroxidase activity. Maximum activity was exhibited at $\mathrm{pH} 5.5,6.0$ and 6.5 for UR, AR and RP samples respectively in the temperature ranges of $10-20{ }^{\circ} \mathrm{C}$; at $90{ }^{\circ} \mathrm{C}$, the enzyme was completely inactivated in all the fruit pulps. These findings suggest that POD in Mangifera indica is stable over wide temperature ranges and could be responsible for deterioration in colour and flavor observed during fruit pulp storage and processing. 
The $\mathrm{Km}$ of 0.283 to $0.477 \mathrm{M}$ using pyrogallol as substrate showed that peroxidase enzyme in unripe, about to ripe and ripe mango fruit pulps could be isolated, purified, characterized and quantitatively made available for biotechnological applications.

\section{REFERENCES}

Jagarlamudi, S.G., Rosaiah, R. K., Kurapati, \& Pinnamaneni, R. (2011). Molecular identification of mango (Mangifera indica). Bioinform, 5: 405-409.

Dube, M., Zunker, K. \& Neidhart, S. (2004). Effect of technological processing on the allergenicity of mangoes (Mang,fera indica L.). Journal of Agriculture and food Chemistry, 52: 3938-3945.

Jimenez - Atienzar, M., Pedreno, M. A., Caballero, J., Cabanes, \& Garcia-Carmona, F. (2007). Characterization of polyphenol oxidase and peroxidase from peach mesocarp (Prunus persica L. cv. Babygold). Journal of Science and Food Agriculture, 87: 16821690.

Ebiloma,S. S., Arobgba, and Amini, O. R. (2011). Some activities of peroxidase from mango kernel. International Journal of Biological Chemistry, 5(3): 200-206.

Kumar, P., Bandaru, V., Ganesh, S., Raju, K. \& Sukumaran, M. (2017). Evaluation of peroxidase Activity in Selected Vegetables from Hyderabad, Telangana, India. Int. Journal of Current Research in Biosciences and Plant Biology, 4(8): 106-110.

Clemente, E. (2002). Peroxidase from oranges (Citrus sinensis L.) Osbeck). Eur. Food Res. Technol. $215,164-168$.

Neves, V. A. (2002). Ionically bound peroxidase from peach fruit. Braz. Arch. Biol, Technol. 45, 7-16

Regalado, C., Garcia-Almendiarez, B. E., Duarte-Vizquez, M. A. (2004). Biotechnological application of peroxidases. Phytochem. Rev. 3, 243-256. 
Singh, J., Dubey, A., Diwakar, S. K., Rawat, S. K., Batra, N., Josh, A. (2010). Biochemical characterization of peroxidases from the fruits of Mallus pumilus. Int. Res. Journal of Biotechol. 1(14): 50-58.

Valdir, A. N. \& Lourengo, E. J. (1997). Peroxidase from peach fruit: Thermal stability. Brazillian Archives of Biology and Technology, 4(2) 20-28.

Benjawan, C., Chutichudet, P. \& Chanaboon, T. (2006). Effect of gibberellin (GA8) on fruit yield and quality Kaew mango (Mangifera indiea L.). J. Biol. Sci. 9: $1542-1546$.

Alvarez, M. V., Moreira, M. \& Alejandra, P. (2015). Peroxidase activity and sensory quality of ready to cook mixed vegetables for soup: Combined effect of biopreservatives and refrigerated storage. J. of Food Sci. Technol, 35(1): 204-208.

Burnette, F. S. (2006). Peroxidase and its relationships to food, flavor and quality. J. of Food Science, 42(1): 1-6.

Azevedo, A. M., Martins, V. C., Prazeres, D. M., Vojinovic, V., Cabral, J. M., Fonseca, L. P. (2003). Horseradish peroxidase: A valuable tool in biotechnology. Biotechnol. Annu. Rev. 9: 199-247.

Kawak, S.S., Kim, S.K., Lee, M.S., Jung, K.H., Park, I.H., \& Liu, J.R. (1995). Acidic peroxidase from suspension culture of sweet potato. Pytochem. 39(15): 981-984.

Akhtar, S., Khan, A. A., Husain, Q. (2015). Partially purified bitter gourd (Momordica charantia) peroxidase catalyzed decolorization of textile and other industrially important dyes. Bioresour Technol, 96: 1804-1811.

Aujumzia, M., Mamoona, K., Ishtiage, A., Hafiz, M. N. \& Abbas, R. Z. (2011). Comparative study of peroxidase purification from apple and orange seeds. Afri. J. of Biotech., 10(33): 630-633

Fang C. (2007). Characterization of Polyphenol Oxidase and Antioxidants from Pawpaw Fruit. University of Kentucky, cfang2@uky.edu.pp 477-490.

Leja, M., Mareezek, A. \& Ben, J. (2003). Antioxidant properties of two apple cultivars during long term Storage. J. of Food Chem. 80: 303-307.

Ortutu, S. C., Aremu, M. O. \& Bako, S. S. (2016). Activity of peroxidase (POD) extracted from ripe pawpaw (Carica papaya) fruit pulp. FUW Trends in Science and Technology, 1(1): 225-228

Gonzale, E. M., De Ancos, B. \& Cano, M. P. (2000). Partial characterization of peroxidase and polyphenol oxidase activities in blackberry fruits. Journal of Agriculture and Food Chemistry, 48: 5459-5464.

Cano, M. P., Lobo, M. G., Ancos, B. \& Gonzalez, E. M. (1996). Polyphenoloxidase from Spanish hermaphrodite and female papaya (Carica papaya). J. of Agric. and Food Chemistry, 47: 3075-3079.

Ni Eidhin, D. M., Murphy, E. \& O’Beirne, D. (2006). Polyphenoloxidase from apple (Malus domestica borkh): Purification strategies and characterization. J. of Food Sci., 71: 51-58.

Gonzale, E. M., De Ancos, B. \& Cano, M. P. (1999). Partial characterization of peroxidase and polyphenol oxidase activities in raspberry fruits. Journal of Agriculture and Food Chemistry, 48: 4065-4072.

Yang, C. P., Fuyita, S., Kohno, K., Kusubayashi, A., Ashrafuzzaman, M. D. \& Hayashi, N. (2001). Purification and characterization of poluphenoloxidase from banana (Musa sapientum) L.) peel. J. of Agric. and Food Chem., 49: 1446-1449.

Ziyan, E., \& Pekyardimci, S. (2004). Purification and characterization of pear (Pyrus communis) polyphenoloxidase. Turkey J. of Chem., 28: 547-557.

Reed, G. (1975). Oxidase Ductase of Enzymes in Food Processing. Academic press, New Yock. pp. 216

Suha, O. A., Babiker, E. M. \& Babiker, E. E. (2013).Thermostability at different Ph levels of peroxidase extracted from four vegetables. Inter. J. of Food Research, 20(2): 715-719.

Casado-Vela, I., Selles, S. \& Bru, R. (2006). Influence of developmental stage cultivar and hexapeptide and cyclodextrin inhibitors on polyphenoloxidase activity from tomato fruits. J. Food Biochem., 30: 623-640.

John, R. W. (1999). Principles of Encymology for the Food Sciences $\left(6^{\text {th }}\right.$ ed). London Press, London pp. 200-658

Bari, I., Hassan, Absar, N., Khatan, S., \& Hossain, M. I. (2013). Purification and Characterization of peroxidase from Anthraenose Disease infected Papaya (Carica papaya L.). Bangladesh J. of Medical Biochem., 6(2): 62-68.

Silva, E., Lourenco, E. J. \& Nerves, V. A. (2012). Soluble and bound peroxidase from papaya fruit, Phytochem., 29: 1051-1056.

Shukla, S. P., Modi, P. K., Ghosn, \& Devi, S. (2004). Immobilization of horseradish peroxidase by entrapment in natural polysaccharide. J. of Applied Polymer Sci., 91: 2063-2071.

Yu, J., Taylor, K. E., Zou, H., Biewas, N. \& Bewtra, J. K. (1994). Phenol conversion and dimeric intermediates in horseradish peroxidase-catalyzed phenol removed from water. J. of Environm. and Sci. Techno., 28; 2154-2160.

Sarika, D., Kumar, P., Sukumaran, M., Arshad, S. (2015). Purification and evaluation of horseradish peroxidase activity. Int. J. Curr. Microbiol. Appl. Sci. 4(7): 367-375. 
International Journal of Scientific and Research Publications, Volume 11, Issue 9, September 2021 